\title{
Identification of milk proteins enhancing the antimicrobial activity of lactoferrin and lactoferricin
}

\author{
M. Murata, ${ }^{1}$ H. Wakabayashi, K. Yamauchi, and F. Abe \\ Food Science and Technology Institute, Morinaga Milk Industry Co. Ltd., 5-1-83 Higashihara, Zama-City, Kanagawa, 252-8583 Japan
}

\begin{abstract}
Lactoferrin (LF) is known as an iron-binding antimicrobial protein present in exocrine secretions such as milk and releases the potent antimicrobial peptide lactoferricin (LFcin) by hydrolysis with pepsin. The antimicrobial activity of LF and LFcin has been studied well; however, their cooperative action with other milk proteins remains to be elucidated. In this study, we identified milk proteins enhancing the antimicrobial activity of bovine LF and LFcin against gram-negative bacteria, gram-positive bacteria, and fungi. As the target fraction, we isolated a minor milk protein fraction around $15 \mathrm{kDa}$, which was identified as bovine RNase 5 (angiogenin-1), RNase 4, and angiogenin-2 by matrixassisted laser desorption/ionization-time-of-flight mass spectrometry. As these proteins are collectively known as the RNase A family, we referred to the target protein fraction as milk RNase of $15 \mathrm{kDa}$ (MR15). The number of colony-forming units of Escherichia coli and other pathogenic microorganisms with the addition of MR15 to $\mathrm{LF}$ (MR15:LF ratio $=16: 1,000)$ was dramatically lowered than that with LF alone. On the other hand, MR15 itself did not show any reductions in the number of colony-forming units at the concentrations tested. Similarly, the antimicrobial activities of LFcin against various microorganisms were significantly enhanced by the addition of MR15. These results suggest that LF and MR15 may be concomitantly acting antimicrobial agents in milk.
\end{abstract}

Key words: lactoferrin, lactoferricin, milk-derived RNase, antimicrobial activity

\section{INTRODUCTION}

Lactoferrin ( $\mathbf{L F})$, an iron-binding glycoprotein of the transferrin family, is present in milk, tears, saliva and most other exocrine body fluids. Lactoferrin has been considered to play a host defensive role at mucosal surfaces. Lactoferrin exhibits antimicrobial activity

Received January 24, 2013.

Accepted May 5, 2013.

${ }^{1}$ Corresponding author: m-murata@morinagamilk.co.jp against Escherichia coli, Streptococcus mutans, Candida albicans, and a variety of other pathogenic microorganisms (Arnold et al., 1980). Lactoferrin has iron-binding capacity and also binds to the outer membrane of gram-negative bacteria, resulting in the release of LPS (Ellison et al., 1988). It has been shown that pepsinhydrolyzed LF (LF-hyd) has stronger antimicrobial activity than the undigested protein (Bellamy et al., 1992b). A potent antimicrobial peptide named lactoferricin (LFcin) was isolated from LF-hyd (Bellamy et al., 1992a).

Lactoferrin is an innate-defense protein and a component of milk. In previous studies, lysozyme and IgA, components in milk, have been reported to have synergistic effects with LF for growth inhibition of $E$. coli (Rogers and Synge, 1978; Ellison and Giehl, 1991). It is also known that combinations of various antimicrobial drugs (Wakabayashi et al., 1996; Wakabayashi et al., 2002) and antimicrobial peptides, including nisin (Murdock et al., 2007) and $\beta$-defensin 2 (Bals et al., 1998), enhance the antimicrobial activity of LF in a synergistic manner. To date, a large number of minor proteins in bovine milk have been identified by proteomic methods (Smolenski et al., 2007); however, the interactions among such minor milk proteins and their roles in the host-defensive effect have not been elucidated in detail. As previous studies suggested that some agents can act as enhancers of antimicrobial activity of LF, we investigated whether minor components of bovine milk have any influence on the antimicrobial activity of LF.

\section{MATERIALS AND METHODS}

\section{Sample Preparation}

Preparation of LF, LF Pepsin Hydrolysate, and LFcin. Bovine LF was purified from fresh skim milk by cation-exchange chromatography. The hydrolysate of bovine LF (LF-hyd) and the antimicrobial peptide LFcin B were produced by methods reported previously (Tomita et al., 2002). Briefly, LF-hyd was produced by digestion of LF with porcine pepsin. The LFcin B was isolated from LF-hyd and validated by reverse-phase HPLC. 
Isolation of Milk Protein Fractions Using Cation-Exchange Chromatography. Fresh skim milk was stored at $4^{\circ} \mathrm{C}$ until use. The target protein fraction was prepared by cation-exchange chromatography by the following procedure: skim milk was incubated in a rotating shaker with CM Sephadex C-50 resin (GE Healthcare Bio-Sciences AB, Uppsala, Sweden) at $4^{\circ} \mathrm{C}$. The CM Sephadex C-50 resin was washed with deionized water, which was followed by elution with 0.27 $M \mathrm{NaCl}$ and $1.7 M \mathrm{NaCl}$ in series, to obtain protein fractions.

Membrane Separation of Target Protein Fractions. The eluate from the cation-exchange resin was adjusted with $0.5 \mathrm{M} \mathrm{NaCl}$ solution and permeated by centrifugal ultrafiltration of molecular weight cutoff (MWCO) 30,000 (Amicon Ultra 30K; Millipore, Merck, Darmstadt, Germany). Then, the permeate from ultrafiltration of MWCO 30,000 was desalted and concentrated using centrifugal ultrafiltration of MWCO 10,000 (Amicon Ultra 10K; Millipore, Merck) with the addition of deionized water. Concentrations of protein fractions were determined by measuring the absorbance at $280 \mathrm{~nm}$ with a spectrophotometer. Fractions were collected and were characterized by SDS-PAGE and mass spectrometry, and tested for antimicrobial activity.

Gel Filtration Chromatography. The eluate of the cation-exchange resin was dissolved in $20 \mathrm{~m} M$ citrate buffer $(0.5 \mathrm{M} \mathrm{NaCl}, \mathrm{pH} 5.2)$ at $5 \mathrm{mg} / \mathrm{mL}$. This solution was applied to the TSKgel filtration column (TSKgel 2000SW; Tosoh Corp., Tokyo, Japan) connected to an HPLC system (Hitachi, Ibaraki, Japan), including an L-5200 Intelligent Pump, L-4000 UV detector, and D-2500 Chromato-Integrator. HPLC separation was performed using $20 \mathrm{~m} M$ citrate buffer $(0.5 \mathrm{M} \mathrm{NaCl}, \mathrm{pH}$ 5.2 ) at a flow rate of $3.0 \mathrm{~mL} / \mathrm{min}$.

\section{Analytical Methods of the Protein Fraction}

$\boldsymbol{S D S}-\boldsymbol{P A} \boldsymbol{G E}$. The membrane-separated protein fraction was analyzed by SDS-PAGE. The protein fraction from ultrafiltration between MWCO 30,000 and 10,000 was diluted with NuPAGE lithium dodecyl sulfate (LDS) sample buffer (Invitrogen, Life Technologies Corp., Carlsbad, CA) containing $\beta$-mercaptoethanol and was heated in a block incubator (BI-525A; Astec Co. Ltd., Fukuoka, Japan) at $70^{\circ} \mathrm{C}$ for $10 \mathrm{~min}$; NuPAGE 4 to $12 \%$ Bis-Tris gel (Invitrogen) and 3-(N-morpholino)propanesulfonic acid (MOPS) or 2-(N-morpholino) ethanesulfonic acid (MES) running buffer (Invitrogen) were used. Electrophoresis was performed at $200 \mathrm{~V}$ for $45 \mathrm{~min}$. Imaging of protein bands on gels stained with SimplyBlue SafeStain (Invitrogen) was captured by a Densitograph AE-6920 image sensor (Atto Corp., To- kyo, Japan) and analyzed by a Lane and Spot Analyzer version 6.0 (Atto Corp.).

Two-Dimensional SDS-PAGE. The membraneseparated protein fraction was analyzed by 2-dimensional SDS-PAGE (2-dimensional gel electrophoresis, 2D-GE). For 2D-GE, a ZOOM IPGRunner system (Invitrogen) was used. The target fraction sample was separated based on the intrinsic charge as the first dimension by isoelectric focusing with rehydrated immobilized $\mathrm{pH}$ gradient ZOOM strips $\mathrm{pH} 3$ to 10 . Then, proteins were separated based on mass as the second dimension using NuPAGE Novex 4 to $12 \%$ Bis-Tris ZOOM gels and MOPS running buffer. The 2D-GE was performed at $200 \mathrm{~V}$ for 35 to $50 \mathrm{~min}$. Protein bands on gels were stained with SimplyBlue SafeStain (Invitrogen) and images were captured in the same manner as SDS-PAGE.

Matrix-Assisted Laser Desorption/IonizationTime-of-Flight Mass Spectrometry. Mass spectrometric analysis of target proteins was performed using a matrix-assisted laser desorption/ionization-time-offlight mass spectrometry (MALDI-TOF MS) autoflex II instrument (Bruker Daltonics Inc., Billerica, MA). Visible protein spots were excised from SDSPAGE or 2-dimensional SDS-PAGE gels and destained. Destained gel pieces were processed to in-gel protein digestion using trypsin. Peptides were extracted from gel pieces and desalted by ZipTip C18 pipette tips (Millipore, Merck). The purified peptide solution was spotted onto a MALDI sample plate. Then, MALDI-TOF MS was performed and the peaks of the peptides were detected using the MALDI-TOF instrument.

Protein identification was carried out using the MALDI-TOF mass spectral data matching search engine Mascot (Matrix Science Ltd., London, UK). The MS data were searched against the National Center for Biotechnology Information (NCBI, Bethesda, MD) database. Protein matches were considered to be valid if there were at least 6 matched peptides with Mascot scores summing greater than $67(P<0.05)$.

\section{Antimicrobial Testing}

Bacteria Strains and Culture. For gram-negative bacteria, the following 6 strains were used: E. coli K-12 [NITE Biological Resource Center (NBRC) 3301], E. coli O111, Cronobacter sakazakii American Type Culture Collection (ATCC) 12868, Salmonella enteritidis IID 604, Klebsiella pneumoniae JCM 1662T, and Pseudomonas aeruginosa MMI 603. For gram-positive bacteria, the following 2 strains were used: Staphylococcus aureus JCM 2151, and Strep. mutans JCM 5705T. For fungi, C. albicans TIMM 1768 was used. The following bacteria were incubated in $1 \%$ Bacto Peptone 
broth (Becton, Dickinson and Co., Franklin Lakes, NJ): E. coli K-12, E. coli O111, Cronobacter sakazakii ATCC 12868, Salmonella enteritidis IID604, Klebsiella pneumoniae JCM 1662T, and Pseudomonas aeruginosa MMI 603. Strep. mutans JCM 5705T was incubated in PYG broth containing 1\% Bacto Peptone, 1\% glucose (Wako Pure Chemical Industries Ltd., Osaka, Japan), and $0.05 \%$ yeast extract (Becton, Dickinson and Co.). Candida albicans TIMM 1768 was incubated in Sabouraud broth containing 1\% Bacto Peptone, and 2\% glucose (Wako Pure Chemical Industries Ltd.).

Effect of the Target Protein Fraction on Antimicrobial Activity of LF, LF-hyd, and LFcin. To determine the antimicrobial activity, we conducted 2 types of tests. For the colony-forming units assay, about $10^{6}$ viable cells $/ \mathrm{mL}$ of $E$. coli $\mathrm{K}-12$ preincubated for $6 \mathrm{~h}$ at $37^{\circ} \mathrm{C}$ were used as an inoculum. Test bacteria were incubated in 1\% Bacto Peptone broth for indicated time at $37^{\circ} \mathrm{C}$ in the presence of $\mathrm{LF}(2,000 \mu \mathrm{g} /$ $\mathrm{mL})$, LF-hyd $(400 \mu \mathrm{g} / \mathrm{mL})$, or LFcin B $(8 \mu \mathrm{g} / \mathrm{mL})$ with target protein fractions. The control culture contained all components except for test proteins or peptides. To determine the number of colony-forming units, serial 10fold dilutions were prepared in $0.85 \% \mathrm{NaCl}$ and plated onto Rapid Media RM-SPC agar plates (Morinaga Milk Industry Co. Ltd., Tokyo, Japan). After incubation of the plates for $16 \mathrm{~h}$, the number of colony-forming units was determined. The detection limit was set to $250 \mathrm{cfu} /$ $\mathrm{mL}$. Each sample was tested in triplicate. To determine the MIC, 2-fold serial dilutions of LF and LFcin B were tested. About $10^{6}$ viable cells $/ \mathrm{mL}$ of test bacteria were used as an inoculum. The test bacteria, except for Strep. mutans and C. albicans, were incubated in $1 \%$ Bacto Peptone broth at $37^{\circ} \mathrm{C}$ for the indicated time in the presence of LF, LF-hyd, or LFcin B, with target protein fractions in a 96-well microtiter plate (Becton, Dickinson and Co.). For Strep. mutans, PYG broth was used as the test medium. For C. albicans, Sabouraud broth was used as the test medium. The control culture contained all components except for test proteins or peptides. After incubation for the indicated time, the MIC was determined by measuring the absorbance at $630 \mathrm{~nm}$ by a microplate reader (Corona Electric Co. Ltd., Ibaraki, Japan). The MIC was determined as the lowest concentration of target protein and LF or LFcin $\mathrm{B}$ to inhibit the growth of the test bacteria to $50 \%$ of control.

\section{Statistical Analysis}

The colony-forming unit data were expressed as mean \pm standard deviation. The Student's $t$-test was used for intergroup comparisons of antimicrobial activity and $P$ $<0.05$ was regarded to be significantly different.

\section{RESULTS}

\section{Isolation of the Target Protein Fraction}

Our preliminary experimental results indicated that the crude milk-protein fraction from cation-exchange chromatography, containing basic proteins such as LF and others along with a minute amount of proteins around $15 \mathrm{kDa}$ (Figure 1, lane 1), exhibited a markedly higher antimicrobial activity against $E$. coli than that with highly purified LF. Therefore, we noted this protein fraction around $15 \mathrm{kDa}$ as the target. Using membrane separation, we separated and concentrated the target fraction with a molecular size between 10 and 30 $\mathrm{kDa}$ from the crude cation chromatography eluate. The purity of the target protein fraction was determined by SDS-PAGE. After the purification procedure, the target protein around $15 \mathrm{kDa}$ (Figure 1, lane 3) was separated from the higher molecular protein around $80 \mathrm{kDa}$, which was mainly LF (Figure 1, lane 2). The purity of the target protein fraction around $15 \mathrm{kDa}$ was $>98 \%$.

\section{Effects of the Target Protein Fraction on the Antimicrobial Activity of LF-Related Compounds Against E. coli K-12}

First, the antimicrobial activity of LF against E. coli $\mathrm{K}-12$ was evaluated in the presence or absence of the target protein fraction around $15 \mathrm{kDa}$ by colony-forming unit tests (Figure $2 \mathrm{a}$ ). After incubation at $37^{\circ} \mathrm{C}$ for $17 \mathrm{~h}$, E. coli K-12 was grown from $10^{6}$ to $10^{8} \mathrm{cfu} / \mathrm{mL}$ in the control culture. The addition of $\operatorname{LF}(2,000 \mu \mathrm{g} / \mathrm{mL})$ alone decreased the number of colony-forming units of E. coli $\mathrm{K}-12$ to about $10^{6} \mathrm{cfu} / \mathrm{mL}$, which is the bacteriostatic effect reported in previous studies. Furthermore, the addition of the target protein fraction around 15 $\mathrm{kDa}(32 \mu \mathrm{g} / \mathrm{mL})$ to $\mathrm{LF}(2,000 \mu \mathrm{g} / \mathrm{mL})$ dramatically decreased the number of colony-forming units of $E$. coli $\mathrm{K}-12$ to less than $250 \mathrm{cfu} / \mathrm{mL}$ (detection limit; $P<0.05$ for target protein addition to LF vs. LF alone). On the other hand, the addition of the target protein fraction $(32 \mu \mathrm{g} / \mathrm{mL})$ alone did not cause any reductions in the number of colony-forming units after $17 \mathrm{~h}$ of incubation. Similarly, antimicrobial activity tests using LFhyd and LFcin B were performed. In the LF-hyd test, the addition of LF-hyd $(400 \mu \mathrm{g} / \mathrm{mL})$ alone decreased the number of colony-forming units of E. coli K-12 to $10^{5} \mathrm{cfu} / \mathrm{mL}$ after $17 \mathrm{~h}$ of incubation (Figure $2 \mathrm{~b}$ ). The addition of the target protein fraction around $15 \mathrm{kDa}$ $(32 \mu \mathrm{g} / \mathrm{mL})$ to LF-hyd $(400 \mu \mathrm{g} / \mathrm{mL})$ clearly decreased the number of colony-forming units of $E$. coli K-12 to less than $250 \mathrm{cfu} / \mathrm{mL}$ (detection limit; $P<0.05$ for target protein addition to LF-hyd vs. LF-hyd alone). The 


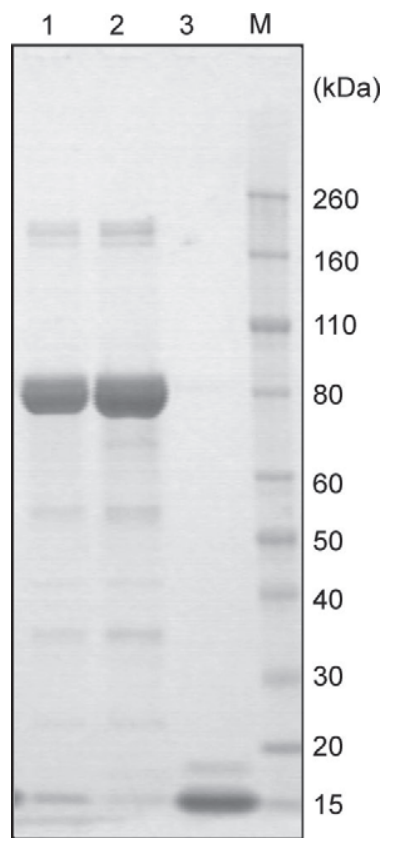

Figure 1. Sodium dodecyl sulfate PAGE analysis of fractions during different stages of purification of the target protein fraction around $15 \mathrm{kDa}$ from bovine milk. Lane $1=$ the initial eluate fraction including the target protein around $15 \mathrm{kDa}$ after cation chromatography; lane 2 $=$ retentate of UF molecular weight cutoff (MWCO) 30,000; lane $3=$ the target protein-enriched fraction (permeate of UF MWCO 30,000); $\mathrm{M}=$ molecular weight markers

target protein fraction also showed an enhancing effect on the antimicrobial activity of LFcin B $(P<0.05$ for target protein addition to LFcin B vs. LFcin B alone), the same as for LF and LF-hyd (Figure 2c).

\section{Identification of Proteins Enhancing the Antimicrobial Activity of LF-Related Compounds}

To analyze the composition of the target protein fraction, the eluate fraction including the target protein of $15 \mathrm{kDa}$ was separated by 2D-GE and proteins were identified using MALDI-TOF MS. A proteomic map of the eluate fraction is shown in Figure 3, with accompanying data on protein identification given in Table 1. The stained 2D-GE gel gave a pattern of spots with clearly dominant proteins/peptides in relatively lower mass and high isoelectric point ( $\mathbf{p I}$ ) regions of the gel. The molecular weight distribution at pI 9 (vertical line) was accounted for by densitometric analysis of these spots. The minute amount of the $40-\mathrm{kDa}$ spot (1.4\%), $30-\mathrm{kDa}$ spot (12\%), 17-kDa spot (8.4\%), and an abundance of 14 - to $15-\mathrm{kDa}$ spots $(78 \%)$ were also observed (data not shown).

As shown in Table 1, MALDI-TOF MS spectra of these spots revealed that proteins of 15 and $30 \mathrm{kDa}$ were bovine RNase 5 , the protein of $14 \mathrm{kDa}$ was bovine
RNase 4 , and the protein of $17 \mathrm{kDa}$ was bovine angiogenin (ANG)-2. Several other lower-molecular weight forms of RNase- 5 were also identified in the basic pI range, although at very low levels (Figure 3 ). A trace amount of an $80-\mathrm{kDa}$ spot (1.4\% of total protein) was identified as bovine LF. As these proteins, including RNase 5, RNase 4, and ANG-2, are known as milkRNases belonging to RNase A family, we referred to the target protein fraction as milk RNase of $15 \mathrm{kDa}$ (MR15)

\section{The Effects of Further Purified Milk RNases on the Antimicrobial Activity of LF}

To validate that each milk RNase identified from the target fraction has an antimicrobial activity-enhancing effect, we conducted isolation of RNase 5 , RNase 4, and ANG-2. Using gel filtration chromatography, 3 subfractions, including F1 (RNase 5 + ANG-2), F2 (RNase 5), and F3 (RNase 4) to LF were separated and confirmed by SDS-PAGE and MALDI-TOF MS analysis (Figure 4).

The antimicrobial activity-enhancing effect of each of RNase 5, RNase 4, and RNase $5+$ ANG-2 was confirmed by combining with LF, using the same method as for the whole fraction described above. As shown in Figure 5 , the 3 isolated subfractions [F1 (RNase $5+$ ANG-2), F2 (RNase 5), and F3 (RNase 4)] themselves did not show any reductions in the number of colonyforming units after $17 \mathrm{~h}$ of incubation. Addition of each isolated subfraction [F1 (RNase $5+$ ANG-2), F2 (RNase 5), F3 (RNase 4)] provided significant reductions in the number of colony-forming units relative to LF alone $(P<0.05)$. However, the reduction rates of the number of colony-forming units by LF with these subfractions (F1, F2, and F3) and the mixed fractions $(\mathrm{F} 1+\mathrm{F} 3$ and F2 + F3) were relatively weaker (3.5 to $4.5 \log _{10} \mathrm{cfu} / \mathrm{mL}$ reduction) than that by LF with the whole MR15 fraction (shown in Figure 2a; $5.4 \log _{10} \mathrm{cfu} /$ $\mathrm{mL}$ reduction).

\section{Antimicrobial Activity of LF and LFcin B with MR15 Against Various Pathogens}

Because the antimicrobial activity of LF-related compounds (LF, LF-hyd, and LFcin B) against $E$. coli K-12 was potently enhanced, we performed MIC tests against other various microorganisms. As shown in Tables 2 and 3, the growth of all microorganisms tested was not inhibited by the addition of MR15 (32 $\mu \mathrm{g} / \mathrm{mL}$ ) alone. With the addition of MR15 against all microorganisms tested, MIC of LF were reduced 2-fold to 16 -fold (Table 2). In the same manner as LF, the MIC of LFcin B were also reduced 2-fold to 4-fold when 

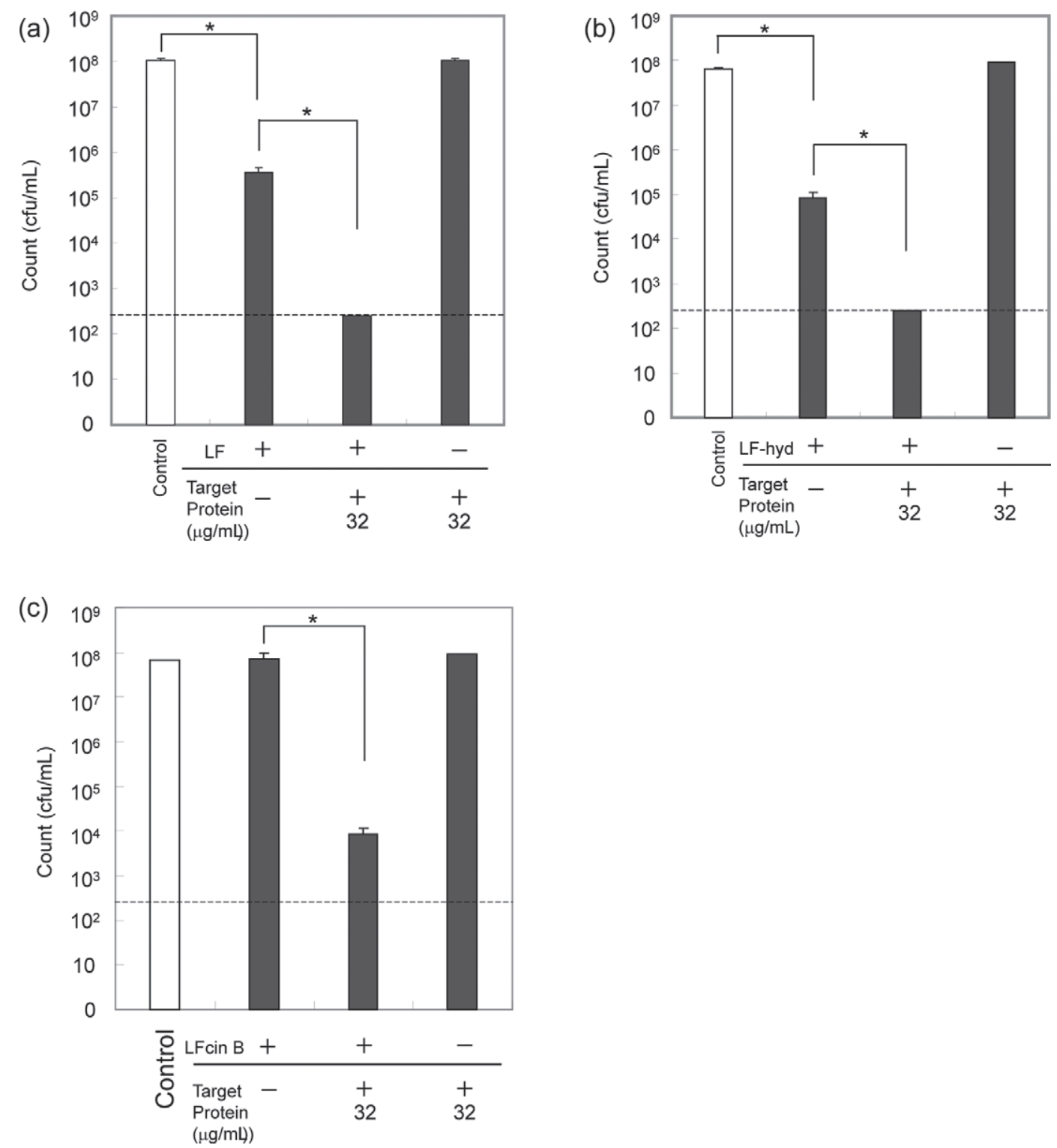

Figure 2. Effect of the addition of the target protein around $15 \mathrm{kDa}$ on the antimicrobial activity of lactoferrin (LF; a), pepsin-hydrolyzed LF (LF-hyd; b), or lactoferricin B (LFcin B; c) against Escherichia coli K-12. The antimicrobial activity of LF $(2,000 \mu \mathrm{g} / \mathrm{mL}), \mathrm{LF}-\mathrm{hyd}$ (400 $\mu \mathrm{g} /$ $\mathrm{mL})$, and LFcin B $(8 \mu \mathrm{g} / \mathrm{mL})$ were determined by plating cells after incubation for $17 \mathrm{~h}$ and counting colonies on the agar plate. Results are means of 3 tests per condition, with standard deviations denoted by error bars. ${ }^{*} P<0.05$ (significantly different for the results for control, LF, LF-hyd, or LFcin B). Dotted lines indicate the detection limit $(250 \mathrm{cfu} / \mathrm{mL})$.

used together with MR15 $(32 \mu \mathrm{g} / \mathrm{mL})$ against all species tested (Table 3 ).

\section{DISCUSSION}

In previous animal and human studies, oral administration of LF alone was shown to improve intestinal bacterial flora (Roberts et al., 1992; Teraguchi et al., 1995a,b). Recently, it has become evident that oral administration of LF exerts various beneficial health effects such as antiinfective activities not only in infants, but also in adult animals and humans (Wakabayashi et al., 2006; Tomita et al., 2009).

In this study, we isolated a protein fraction around 15 $\mathrm{kDa}$, which enhanced the antimicrobial activity of LF, from bovine milk by cation-exchange chromatography and ultrafiltration. Proteins around $15 \mathrm{kDa}$ in this fraction were identified as bovine RNases, including RNase 4, RNase 5 (ANG-1), and ANG-2, reported as the minor components of bovine milk. These proteins belong to the RNase A family and we referred to the protein fraction as milk RNase of $15 \mathrm{kDa}$ (MR15). Further- 
Table 1. Results of the identification of the protein fraction by matrix-assisted laser desorption/ionization-time-of-flight mass spectrometry (MALDI-TOF MS) analysis

\begin{tabular}{lclrr}
\hline $\begin{array}{l}\text { Source of } \\
\text { organism }\end{array}$ & $\begin{array}{c}\text { Molecular } \\
\text { weight }(\mathrm{kDa})\end{array}$ & Protein & $\begin{array}{c}\text { Mascot } \\
\text { protein score }^{1}\end{array}$ & $\begin{array}{c}\text { Number of mass } \\
\text { values matched }^{2}\end{array}$ \\
\hline Bos taurus & 40 & Bovine lactoferrin & 96 & 11 \\
Bos taurus & 17 & Bovine angiogenin-2 (ANG-2) & 73 & 6 \\
Bos taurus & 15 & Bovine angiogenin-1 (RNase 5) & 140 & 15 \\
Bos taurus & 14 & Bovine RNase 4 & 102 & 9.52 \\
\hline
\end{tabular}

${ }^{1}$ Protein scores greater than 67 are significant $(P<0.05)$. Scores were determined using the MALDI-TOF mass spectral data matching search engine Mascot (Matrix Science Ltd., London, UK).

${ }^{2}$ Isoelectric point.

more, our results indicated that MR15 could enhance the antimicrobial activity of LF-hyd and LFcin B in a manner similar to LF.

As shown in Figure 5, the 3 subfractions of MR15 isolated by gel filtration chromatography, including F1 (RNase 5 + ANG-2), F2 (RNase 5), and F3 (RNase 4), enhanced the antimicrobial activity of LF. However, the reduction rate of the number of colony-forming units by LF with these subfractions was relatively weaker than that by LF with the whole MR15 fraction before gel filtration (Figure 2a). Moreover, when the subfractions of MR15 were remixed again (F1 + F3 and F2 + F3), the antimicrobial activity enhancing effect did not recover to the level before isolation. A similar result was also obtained using F1 + F2 + F3 in another test (data not shown), which means that the antimicrobial activityenhancing effect of MR15 is fully exerted when applied

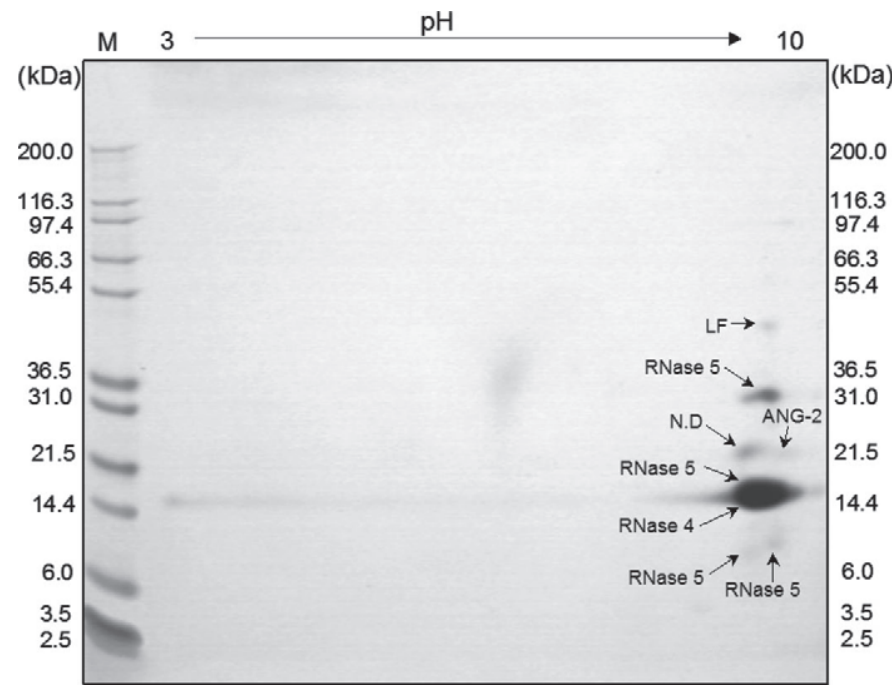

Figure 3. Two-dimensional gel electrophoresis (2D-GE) analysis of the target protein fraction around $15 \mathrm{kDa}$ prepared by ultrafiltration of a cation-exchange eluate fraction of bovine milk. Arrows of each spot indicate proteins identified by matrix-assisted laser desorption/ ionization-time-of-flight mass spectrometry (MALDI-TOF MS) and the National Centre for Biotechnology Information (NCBI, Bethesda, MD) protein database using Mascot search software (Matrix Science Ltd., London, UK). RNase $5=$ angiogenin-1; ANG-2 = angiogenin-2; $\mathrm{M}=$ molecular weight markers as a whole MR15 fraction, but not as a subfraction. For this reason, it is possible that the irreversible complex structure of these components is important in the action of MR15. Analysis of physicochemical features, for example protein-protein interaction among MR15 subfraction proteins or between MR15 and LF, may offer some insights to understanding the mechanisms of action.

Recently, the biological role of RNases, some of them described as ANG, has been attracting attention (Ganz, 2003; Rosenberg, 2008). Many RNase A family proteins, such as eosinophil cationic protein (Rosenberg and Domachowske, 2001) and RNase 7 (Harder and Schröder, 2002; Huang et al., 2006), are highly cationic and are considered to have antiinfective properties. Hooper et al. (2003) found that mouse and human ANG (RNase 5), but not bovine RNase 5, displayed antimicrobial activity, especially against $C$. albicans.

Ribonuclease 5 was originally isolated from the human colon adenocarcinoma cell line HT-29 for its angiogenic activity, and so has been termed ANG (Fett et al., 1985). The presence of proteins with RNase activity in bovine milk was first reported in 1988 (Maes et al., 1988), hereafter referred to as RNase 5. Bovine ANG-2, whose RNase activity, amino acid sequence, and glycosylation profile differ from those of bovine

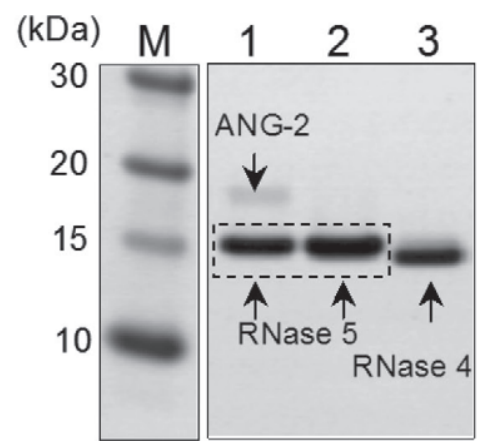

Figure 4. Sodium dodecyl sulfate PAGE analysis of milk RNase of $15 \mathrm{kDa}$ (MR15) subfractions separated by gel filtration chromatography. $\mathrm{M}=$ molecular weight markers; lane $1=\mathrm{F} 1$ [angiogenin-2 $($ ANG-2) + RNase 5]; lane $2=$ F2 (RNase 5); lane $3=$ F3 (RNase 4). 
Table 2. Minimum inhibitory concentrations of lactoferrin (LF) and milk RNase of $15 \mathrm{kDa}$ (MR15) alone or in combination against various microorganisms

\begin{tabular}{lccc}
\hline & \multicolumn{2}{c}{ MIC $^{1}$ of LF $(\mu \mathrm{g} / \mathrm{mL})$} & \\
\cline { 2 - 3 } Test microorganisms & $\begin{array}{c}\mathrm{LF} \\
\text { alone }\end{array}$ & $\begin{array}{c}\text { With MR15 } \\
(32 \mu \mathrm{g} / \mathrm{mL})\end{array}$ & $\begin{array}{c}\mathrm{MIC}^{1} \text { of MR15 } \\
(\mu \mathrm{g} / \mathrm{mL})\end{array}$ \\
\hline Gram-negative bacteria & & & \\
$\quad$ Escherichia coli O111 & 2,000 & 1,000 & $>32$ \\
Cronobacter sakazakii ATCC 12868 & 8,000 & 1,000 & $>32$ \\
Salmonella enteritidis IID 604 & 8,000 & 1,000 & $>32$ \\
Klebsiella pneumoniae JCM 1662T & 8,000 & 1,000 & $>32$ \\
Pseudomonas aeruginosa MMI 603 & 8,000 & 1,000 & $>32$ \\
Gram-positive bacteria & & 125 & $>32$ \\
Staphylococcus aureus JCM 2151 & 500 & 500 & $>32$ \\
Streptococcus mutans JCM 5705T & 8,000 & 125 & \\
Fungi & 1,000 & & \\
Candida albicans TIMM 1768 & & & \\
\hline
\end{tabular}

${ }^{1}$ The MIC resulting in a $50 \%$ suppression of growth, as measured by absorbance at $630 \mathrm{~nm}$. Results were confirmed in 2 tests.

RNase 5, was also isolated from serum and milk in 1997 (Strydom et al., 1997). However, the inherent roles of these RNases in milk have not been clearly understood for a long time. More recently, Harris and colleagues have reported that RNase 5 isolated from bovine milk suppressed the growth of $C$. albicans, but not any other microorganisms tested, including E. coli, Enterococcus faecalis, Streptococcus pneumoniae, and Pseudomonas aeruginosa (Harris et al., 2010). Harris et al (2010) concluded that the concentrations of RNase 5 required to suppress the growth of C. albicans (MIC: $55 \mu M=825$ $\mu \mathrm{g} / \mathrm{mL}$ ) was higher than that naturally found in milk $(3-19 \mu \mathrm{g} / \mathrm{mL})$. In the same study, the authors demonstrated for the first time the presence of RNase 4 in bovine milk and concluded that RNase 4 did not suppress the growth of any of the microorganisms tested.

Interestingly, a substantial number of antimicrobial proteins are known to contain basic amino acid-rich sequences. As referred to above, all components of MR15 belong to the RNase A superfamily of proteins, recognized for their RNase activity and highly basic properties ( $\mathrm{pI}>9.0)$. The mechanism of action of MR15 has still been unknown; however, it is possible that the electrostatic interaction between MR15 and the bacterial membrane may contribute to strengthen the antimicrobial activity of LF. Further study is needed to elucidate whether RNase activity or any other biochemical activity is essential for the antimicrobial activity-enhancing effect of MR15 toward LF.

\section{CONCLUSIONS}

This is the first report to provide new insight concerning the cooperative action of LF and milk-derived RNases, and the biological importance of their coexistence in milk. The killing activity against a wide range of pathogens of both intact LF and some digested LF (LF-hyd) may be enhanced by their administration with MR15. We suggest that MR15 may have an important role in host defense by acting together with LF, especially in the case of newborn infants. In the future, we would like to study the synergistic effects of ingestion containing MR15 and LF or LF-hyd on

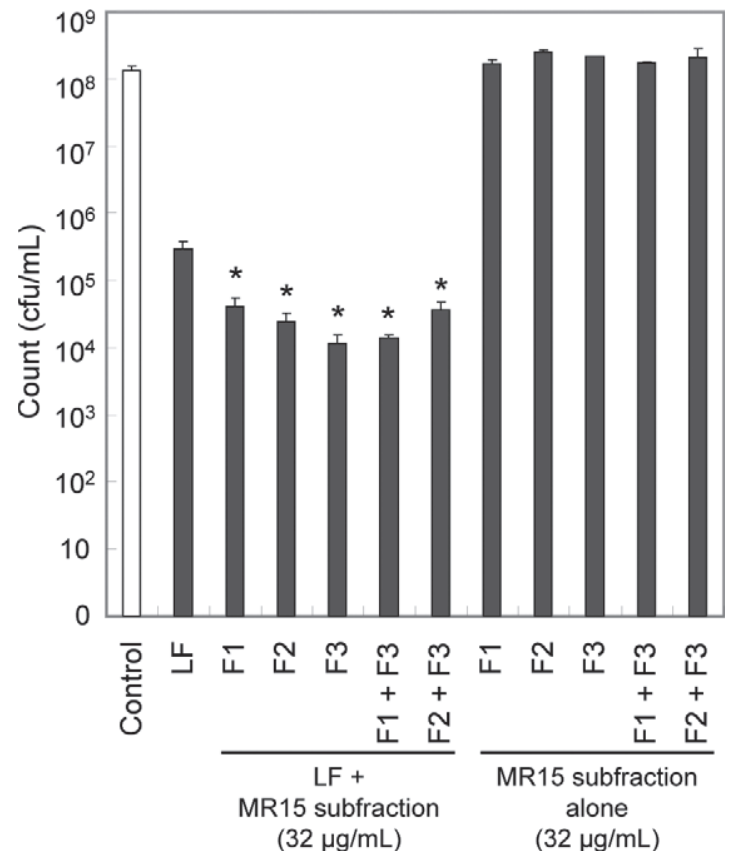

Figure 5. Effect of the addition of separated milk RNase of 15 kDa (MR15) subfractions on the antimicrobial activity of lactoferrin (LF) against Escherichia coli K-12. The antimicrobial activity of LF, F1 (angiogenin-2 + RNase 5), F2 (RNase 5), F3 (RNase 4), and their combinations was determined by plating cells after incubation for $17 \mathrm{~h}$ and counting colonies on the agar plate. Results are means of 3 tests, with standard deviations denoted by error bars. ${ }^{*} P<0.05$ (vs. LF). 
Table 3. Minimum inhibitory concentrations of lactoferricin B (LFcin B) and milk RNase of $15 \mathrm{kDa}$ (MR15) alone or in combination against various microorganisms

\begin{tabular}{lccc}
\hline & \multicolumn{2}{c}{ MIC $^{1}$ of LFcin B $(\mu \mathrm{g} / \mathrm{mL})$} & \\
\cline { 2 - 3 } Test microorganisms & $\begin{array}{c}\text { LFcin } \\
\text { B alone }\end{array}$ & $\begin{array}{c}\text { With MR15 } \\
(32 \mu \mathrm{g} / \mathrm{mL})\end{array}$ & $\begin{array}{c}\text { MIC }^{1} \text { of MR15 } \\
(\mu \mathrm{g} / \mathrm{mL})\end{array}$ \\
\hline Gram-negative bacteria & & & \\
Escherichia coli O111 & 8 & 4 & $>32$ \\
Cronobacter sakazakii ATCC 12868 & 32 & 16 & $>32$ \\
Klebsiella pneumoniae JCM 1662T & 32 & 8 & $>32$ \\
Pseudomonas aeruginosa MMI 603 & 32 & 16 & $>32$ \\
Gram-positive bacteria & 8 & 4 & $>32$ \\
Staphylococcus aureus JCM 2151 & 32 & 8 & $>32$ \\
Streptococcus mutans JCM 5705T & & 32 & $>32$ \\
Fungi & $>32$ & 32 & \\
Candida albicans TIMM 1768 & & & \\
\hline
\end{tabular}

${ }^{1}$ The MIC resulting in a $50 \%$ suppression of growth, as measured by absorbance at $630 \mathrm{~nm}$. Results were confirmed in 2 tests.

protection against infectious diseases and improvement of intestinal flora.

\section{REFERENCES}

Arnold, R. R., M. Brewer, and J. J. Gauthier. 1980. Bactericidal activity of human lactoferrin: Sensitivity of a variety of microorganisms. Infect. Immun. 28:893-898.

Bals, R., X. Wang, Z. Wu, T. Freeman, V. Bafna, M. Zasloff, and J. M. Wilson. 1998. Human $\beta$-defensin 2 is a salt-sensitive peptide antibiotic expressed in human lung. J. Clin. Invest. 102:874-880.

Bellamy, W., M. Takase, H. Wakabayashi, K. Kawase, and M. Tomita. 1992a. Antibacterial spectrum of lactoferricin B, a potent bactericidal peptide derived from the N-terminal region of bovine lactoferrin. J. Appl. Bacteriol. 73:472-479.

Bellamy, W., M. Takase, K. Yamauchi, H. Wakabayashi, K. Kawase, and M. Tomita. 1992b. Identification of the bactericidal domain of lactoferrin. Biochim. Biophys. Acta 1121:130-136.

Ellison, R. T., III, and T. J. Giehl. 1991. Killing of gram-negative bacteria by lactoferrin and lysozyme. J. Clin. Invest. 88:1080-1091.

Ellison, R. T., III, T. J. Giehl, and F. M. LaForce. 1988. Damage of the outer membrane of enteric gram-negative bacteria by lactoferrin and transferrin. Infect. Immun. 56:2774-2781.

Fett, J. W., D. J. Strydom, R. R. Lobb, E. M. Alderman, J. L. Bethune, J. F. Riordan, and B. L. Vallee. 1985. Isolation and characterization of angiogenin, an angiogenic protein from human carcinoma cells. Biochemistry 24:5480-5486.

Ganz, T. 2003. Angiogenin: An antimicrobial ribonuclease. Nat. Immunol. 4:213-214.

Harder, J., and J.-M. Schröder. 2002. RNase 7, a novel innate immune defense antimicrobial protein of healthy human skin. J. Biol. Chem. 277:46779-46784.

Harris, P., K. M. Johannessen, G. Smolenski, M. Callaghan, M. K. Broadhurst, K. Kim, and T. T. Wheeler. 2010. Characterisation of the anti-microbial activity of bovine milk ribonuclease 4 and ribonuclease5 (angiogenin). Int. Dairy J. 20:400-407.

Hooper, L. V., T. S. Stappenbeck, C. V. Hong, and J. I. Gordon. 2003. Angiogenins: A new class of microbicidal proteins involved in innate immunity. Nat. Immunol. 4:269-273.

Huang, Y.-C., Y.-M. Lin, T.-W. Chang, S.-J. Wu, Y.-S. Lee, M. D.-T Chang, C. Chen, S.-H. Wu, and Y.-D. Liao. 2007. The flexible and clustered lysine residues of human ribonuclease 7 are critical for membrane permeability and antimicrobial activity. J. Biol. Chem. 282:4626-4633.

Maes, P., D. Damart, C. Rommens, J. Montreuil, G. Spik, and A. Tartar. 1988. The complete amino acid sequence of bovine milk angiogenin. FEBS Lett. 241:41-45.
Murdock, C. A., J. Cleveland, K. R. Matthews, and M. L. Chikindas. 2007. The synergistic effect of nisin and lactoferrin on the inhibition of Listeria monocytogenes and Escherichia coli O157:H7. Lett. Appl. Microbiol. 44:255-261.

Roberts, A. K., R. Chierici, G. Sawatzki, M. J. Hill, S. Volpato, and V. Vigi. 1992. Supplementation of an adapted formula with bovine lactoferrin: 1. Effect on the infant faecal flora. Acta Paediatr. $81: 119-124$

Rogers, H. J., and C. Synge. 1978. Bacteriostatic effect of human milk on Escherichia coli: The role of IgA. Immunology 34:19-28.

Rosenberg, H. F. 2008. RNase A ribonucleases and host defense: An evolving story. J. Leukoc. Biol. 83:1079-1087.

Rosenberg, H. F., and J. B. Domachowske. 2001. Eosinophils, eosinophil ribonucleases, and their role in host defense against respiratory virus pathogens. J. Leukoc. Biol. 70:691-698.

Smolenski, G., S. Haines, F. Y.-S. Kwan, J. Bond, V. Farr, S. R. Davis, K. Stelwagen, and T. T. Wheeler. 2007. Characterisation of host defence proteins in milk using a proteomic approach. J. Proteome Res. 6:207-215.

Strydom, D. J., M. D. Bond, and B. L. Vallee. 1997. An angiogenic protein from bovine serum and milk-Purification and primary structure of angiogenin-2. Eur. J. Biochem. 247:535-544.

Teraguchi, S., K. Shin, T. Ogata, M. Kingaku, A. Kaino, H. Miyauchi, Y. Fukuwatari, and S. Shimamura. 1995a. Orally administered bovine lactoferrin inhibits bacterial translocation in mice fed bovine milk. Appl. Environ. Microbiol. 61:4131-4134.

Teraguchi, S., K. Shin, K. Ozawa, S. Nakamura, Y. Fukuwatari, S Tsuyuki, H. Namihira, and S. Shimamura. 1995b. Bacteriostatic effect of orally administered bovine lactoferrin on proliferation of Clostridium species in the gut of mice fed bovine milk. Appl. Environ. Microbiol. 61:501-506.

Tomita, M., H. Wakabayashi, K. Shin, K. Yamauchi, T. Yaeshima, and K. Iwatsuki. 2009. Twenty-five years of research on bovine lactoferrin applications. Biochimie 91:52-57.

Tomita, M., H. Wakabayashi, K. Yamauchi, S. Teraguchi, and H. Hayasawa. 2002. Bovine lactoferrin and lactoferricin derived from milk: Production and applications. Biochem. Cell Biol. 80:109-112.

Wakabayashi, H., S. Abe, T. Okutomi, S. Tansho, K. Kawase, and H. Yamaguchi. 1996. Cooperative anti-Candida effects of lactoferrin or its peptides in combination with azole antifungal agents. Microbiol. Immunol. 40:821-825.

Wakabayashi, H., S. Teraguchi, and Y. Tamura. 2002. Increased Staphylococcus-killing activity of an antimicrobial peptide, lactoferricin $\mathrm{B}$, with minocycline and monoacylglycerol. Biosci. Biotechnol. Biochem. 66:2161-2167.

Wakabayashi, H., K. Yamauchi, and M. Takase. 2006. Lactoferrin research, technology and applications. Int. Dairy J. 16:1241-1251. 